The University of Maine

DigitalCommons@UMaine

Maine History Documents

Special Collections

1918

\title{
Natural Bird Gardens on Mount Desert Island
}

Edward Howe Forbush

Follow this and additional works at: https://digitalcommons.library.umaine.edu/mainehistory

Part of the History Commons

\section{Repository Citation}

Forbush, Edward Howe, "Natural Bird Gardens on Mount Desert Island" (1918). Maine History Documents. 79.

https://digitalcommons.library.umaine.edu/mainehistory/79

This Monograph is brought to you for free and open access by DigitalCommons@UMaine. It has been accepted for inclusion in Maine History Documents by an authorized administrator of DigitalCommons@UMaine. For more information, please contact 
Maine

F

27

. M9

S46

v. 15

SIEUR DE MONTS PUBLICATIONS

XV

Natural Bird Gardens on Mount

Desert Island

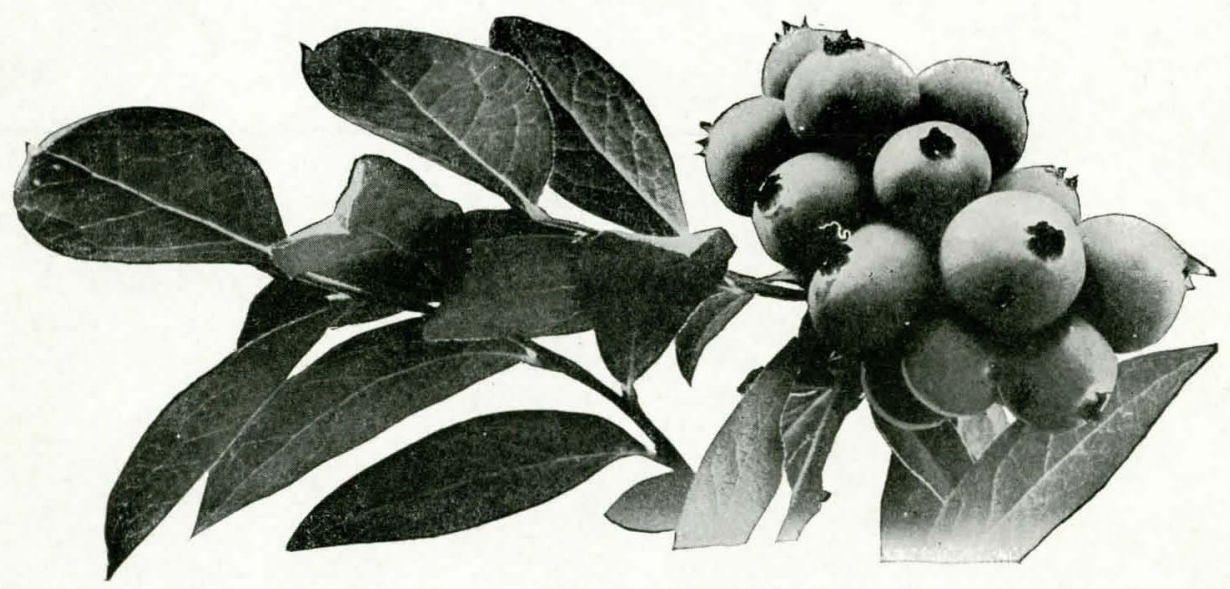

ISSUED BY

THE WILD GARDENS OF ACADIA

BAR HARBOR, MAINE 


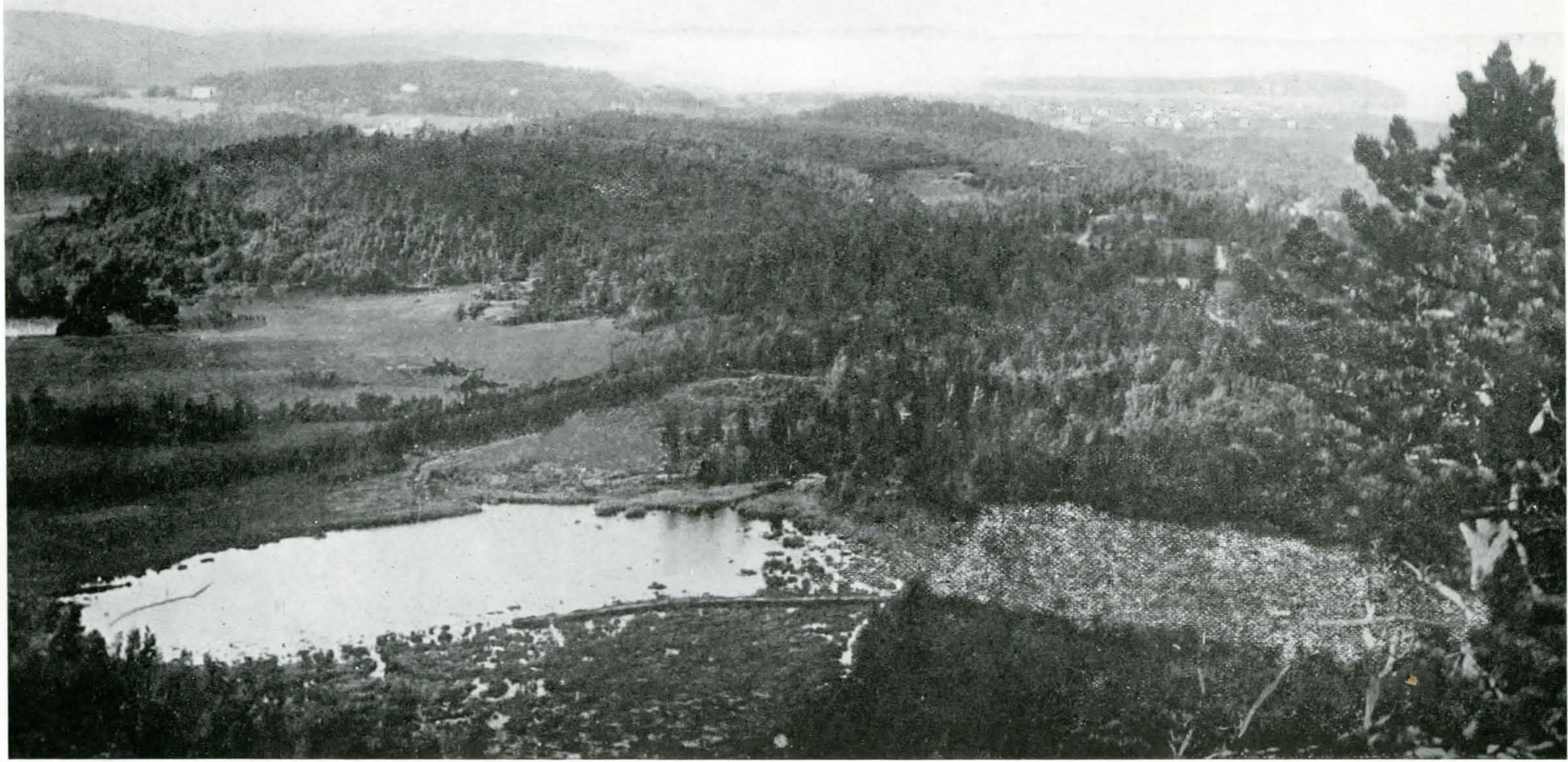

Beaverdam Pool: One of the natural bird gardens described by Mr. Forbush and since deeded to The Wild Gardens of Acadia for a bird sanctuary 


\section{SIEUR DE MONTS PUBLICATIONS}

\section{XV \\ Natural Bird Gardens on Mount \\ Desert Island}

\section{Edward Howe Forbusi}

Massachusetts State Ornithologist, Author of "Useful Birds and Their Protection," a book placed by order of the Massachusetts Legislature in every Public Library and High School in the State; Author of "Game Birds and Wild Fowl."

When America was first discovered the coast of Maine was the habitat of myriads of land and water birds. Marvelous accounts of their abundance have come down to us in the narratives of the early voyagers, and it is indeed a region wonderfully fitted to be a great nesting ground and feeding place for both land and water species. The coast line is so broken with deep, irregular indentations and the islands lying off it are so numerous that from the mouth of the Kennebec at Casco Bay to that of the St. Croix at the Canadian boundary it presents to the wash of the tides more than 2,500 miles of shore. All along the coast there are broad flats and salt-marshes extending deeply inland which are swept over twice a day by the tide's great flood, rising 12 feet or more in the Mount Desert region; and every recurring tide brings in with it and deposits on these flats and marshes quantities of floating marine life, while countless animal and vegetable forms grow on and in their fertile bottoms. In early days, accordingly, when every tide went out 
great multitudes of birds of many species found a bounteous repast spread for them along that vast stretch of coast. Yet, although food conditions are almost as favorable as they were when Champlain first explored these shores, only a pitiable remnant of the birds remains.

The continual hunting and shooting of birds throughout the Atlantic States and the Maritime Provinces, with the destruction of their nests, eggs, and young for food and for commercial purposes, has swept the coast like a destructive storm, annihilating far the greater part of the bird life that formerly existed there. The multitude of swans, snow geese, great auks, wild turkeys, and wild pigeons that were seen by the earlier explorers are gone, and with them are also gone the Labrador ducks, cranes, spruce partridges, and Eskimo curlew, while many other shore birds and water fowl have become rare almost to disappearance, although prompt measures yet would bring them back.

It now seems as though the tide were turning and that the destructive evils of the past may at last be stayed, but the enactment of laws alone will not secure results. All students of the subject now agree that no plan for the preservation of birds in any country can succeed unless adequate and well-selected bird refuges are provided-absolute sanctuaries where all shooting or disturbance is prevented, where the birds that breed locally can nest in safety, and where migratory birds that summer in the farther north can find shelter and protection on their long migrations.

Every year's delay counts heavily against the birds. The forces of destruction are constantly increasing, and the need of sanctuaries where no shooting will ever be allowed has grown urgent to the last degree.

The shape and geographical position of the continent of North America are such that during the migration season, twice a year, bird-life goes crowding up or down 


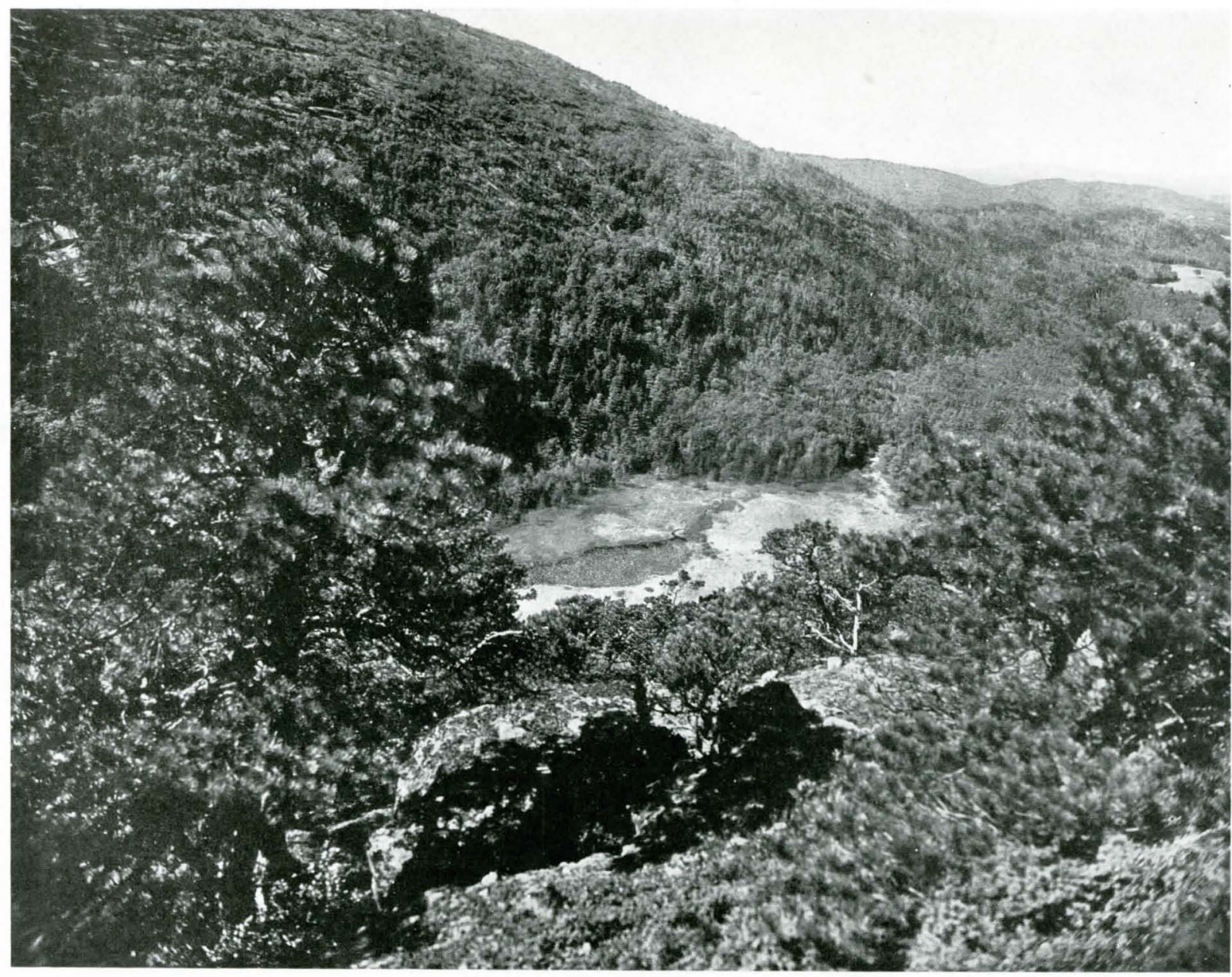

Sieur de Monts Tarn: Another of the natural bird gardens described by Mr. Forbush and now a bird sanctuary under Government protection 
this country's coasts, both east and west. This is due to the increased width and vast extent of the continent to the north of us and to the wonderful feeding ground and natural line of travel offered by the shore to both land and water birds upon their flight.

From the Bay of Fundy southward along the Atlantic Coast this effect of concentration during the migration season is particularly great, and must have rendered it in the early days, when birds were plentiful, a marvelous sight.

Other great highways of migration lie along the Mississippi Valley and the Pacific Coast, and along all three of these great natural routes it is essential that bird reserves and sanctuaries be established. But extensive tracts have been already set aside for this on the Pacific coast, and reservations too, on a great scale, are now in process of establishment in the Mississippi region.

It remains for us in the East, where the bird life was so abundant formerly and the need came earliest, to do like work; and nowhere is there work more urgent to be done, nowhere is the present need so critical.

The tendency of most migratory birds nesting on the eastern third of the continent is to fly southeastward from their nesting grounds until they reach the coast and then to follow it on southward.

Thus when the autumn frosts come, migratory birds from Greenland, from all the shores of Baffins Bay, from Labrador and Newfoundland and the wild interior pour their diminished legions down toward the Maine coast; in the springtime they return and spread out northward from it.

Mount Desert Island, accordingly, unique in being the only mountainous tract thrust prominently out into the sea and rich in meadow lands and valleys, offers an important landmark and admirable resting place for migratory birds of every kind-birds of sea and shore, the useful insect-eating birds of cultivated lands and gar- 


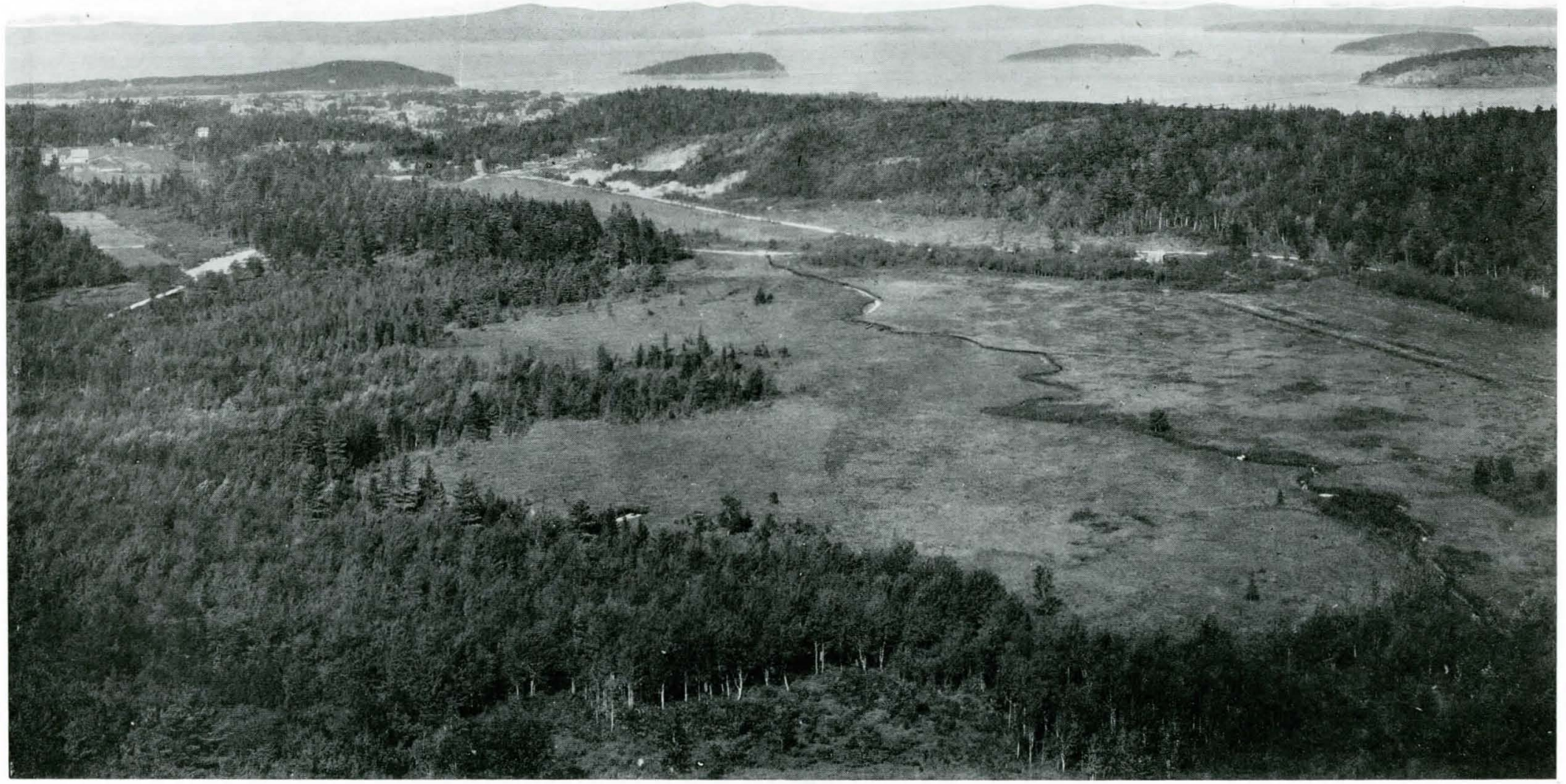

A typical Acadian heath-The view is taken from Sieur de Monts Crag in the national park. At the Crag's foot, Sieur de Monts Spring breaks out and forms the stream that winds across the heath. Bar Harbor is shown in the distance 
dens, the birds of inland waters, woods and marshes.

The fauna and flora of the coast line at this point are largely of the Canadian type and its birds are represented here with corresponding fullness. Nevertheless, a number of Hudsonian plants grow upon the Island also and form breeding places for certain birds characteristic of that northern area. This is one of the very few points on the Atlantic coast of the United States where portions of this far northern flora and fauna can be found at all, and it is the southernmost of all.

Following the coast up from the West and South, a number of the birds of the Alleghenian and Transition zones reach the Island also, and we thus find at least four faunal areas represented in summer at this unique spot, while a number of Arctic and other northern birds frequent the region in winter, at which season the Alaskan eagle and the snowy owl appear.

Remarkable opportunities exist here, accordingly, for inducing birds of many kinds to remain and nest upon the Island, where they can be fostered, studied, and protected. For the birds of farm and garden it offers conditions that might readily be made ideal in certain sections. The forest cover, with its under shrubs, provides admirable nesting places for all woodland species. For the birds of inland and of tidal waters the place is singularly favorable, while the vertical cliffs yet call to nest the raven and the eagle.

No northern situation was ever better fitted to grow a great variety of fruiting plants for bird food. The remarkable horticultural qualities of the Island have long been recognized, and both wild and cultivated shrubs fruit there in extraordinary profusion. In the broad heath which extends from the Bar Harbor region southward to the mountains; in the wild gorge beyond with bottom tarn which makes a natural highway for men and birds alike between the Island's northern and southern shores; and around the old beaver-pool ground out by the 


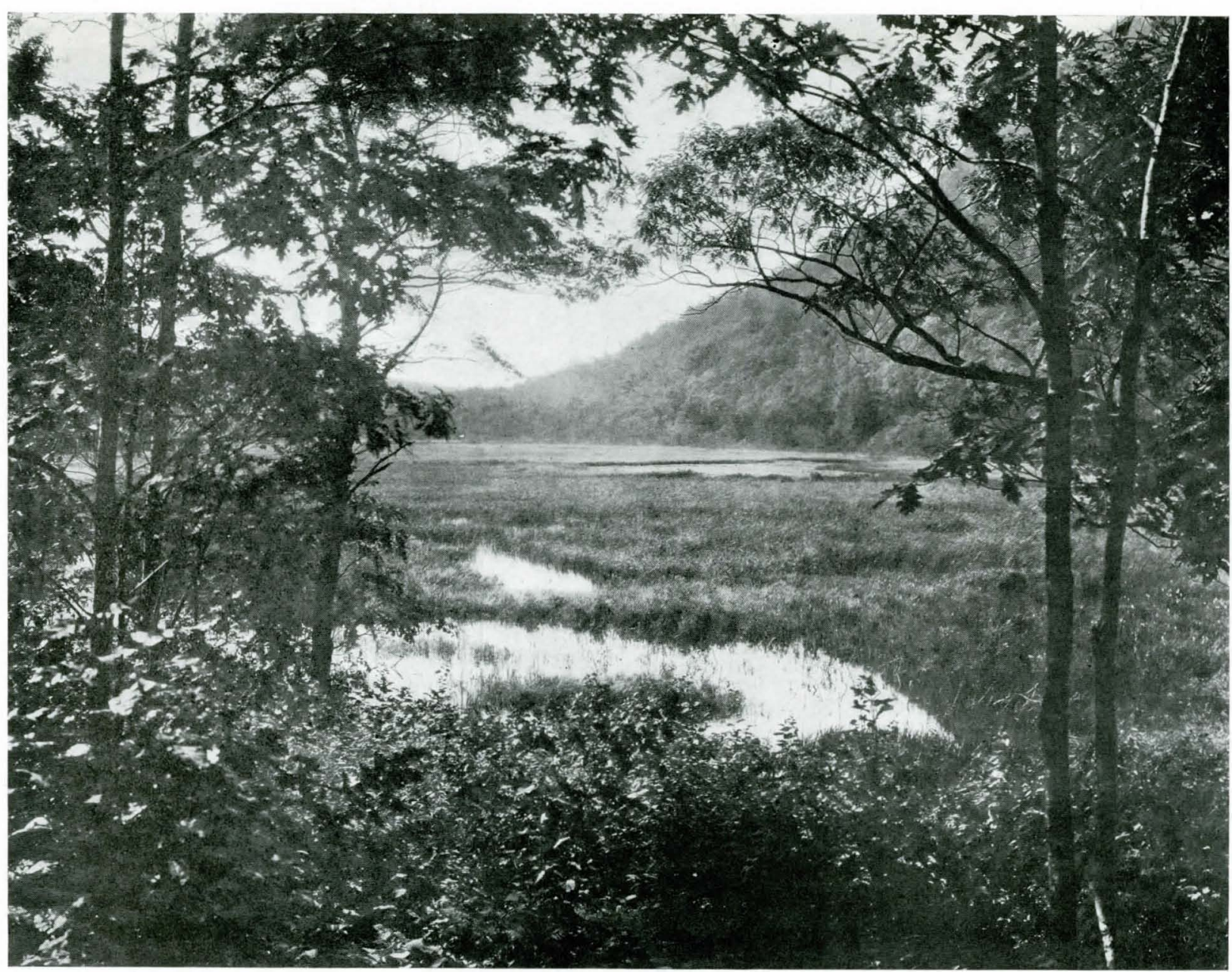

The Gorge that makes a natural highway for birds and men between the Island's Northern and Southern Shores 
Ice-sheet at the northern foot of Newport Mountain, there are wonderful opportunities for natural bird gardens.

Here, in fertile soil washed down from the granite heights above and constantly renewed, open spaces may readily be covered with the native food-providing shrubs and trees, such as the alternate-leaved cornel, the wild service berry or shad blow which is so beautiful in its springtime flowering, the red-berried ilexes and richly fruiting thorns that bring such glowing color into the northern fall, interspersed with thick bushes suitable for nesting.

Here, too, there are excellent opportunities for growing along the banks of streams and ponds the seed-bearing herbaceous plants on which the marsh and water birds subsist so largely, and an admirable chance for creating nesting islands upon flooded marshlands that would form ideal breeding places for meadow and aquatic birds. Water in every form is here abundant-in springs and streams and open pools-while the deep, rich soil of the adjoining swamp and swale already produces plants in plenty to entice the birds that haunt such places, and little more is needed than to give these plants a chance to make their best development.

And here, of all places, an admirable opportunity presents itself for the establishment of a bird-study station combined with bird protection, such as has revolutionized abroad in recent years the methods formerly in use for the encouragement and protection of bird life.

At such a station the best methods of bird protection, food supply and propagation in a northern region would be studied out and given practical trial, and from such a station the results obtained would be published widely for the benefit of the country.

Work along this line is greatly needed in America, and carried out at Mount Desert, where so strong a tide of summer travels sets each year and where so many people of influence and education, drawn from the whole 
country over, spend their summers, such work would have exceptional value.

Nor would the presence of people in the reservation tend to drive out the birds, provided they were not molested. Some even of the wilder birds are learning now to make their home in city parks where they receive protection, and many birds might easily be attracted to a region so favorable for their shelter, sustenance, and nesting as Mount Desert Island. 